Saeculum Christianum vol. XXII (2015)

pp. $236-247$

\author{
KATARZYNA PADUCH* \\ WNHiS UKSW, Warszawa
}

\title{
THE AUTOGRAPH BOOK OF VISITORS IN PODHORCE CASTLE IN THE YEARS 1923-1930
}

The castle in Podhorce was in the 18th and 19th century called the „Pantheon of Galicia”, „Monument of Past Chivalry” and „Wawel of the East”. In the 19th and 20th centuries it enjoyed great interest and popularity among tourists ${ }^{1}$. In Podhorce castle there was a peculiar „national museum” of sorts located in eleven chambers on the first floor of the castle ${ }^{2}$. After the visit guests usually left inscriptions in a special book ${ }^{3}$. The object of this paper will be discussing one of the surviving guest books from the Podhorce castle containing autographs of individuals and groups visiting the castle in the years 1923-1930 ${ }^{4}$. We must stress that Podhorce castle was destroyed as a result of military operations during First World War and the War of 1920. Contemporary owners of the Castle, Konstacja Sanguszko née Zamojska (1864-1946) ${ }^{5}$ and her son Roman Władysław Sanguszko ${ }^{6}$, evacuated precious

\footnotetext{
* Translated by Spektra Sp. z o.o.
}

1 A. Hanaka, Leon Rzewuski kustosz kolekcji w Podhorcach, „Muzealnictwo”, no. 48/2007, p. 69; S.J., Jeszcze coś o Podhorcach (list do przyjaciela.), „Rozmaitości”, no. 34/1828, pp. 279-280; A.P. Pijanowski, Podhorce, „Nowa Szkoła”, no. 9/1997, p. 56; J.M. Marszalska, Biblioteka i Archiwum Sanguszków: zarys dziejów, Tarnów 2000 , p. 129.

2 The detailed description of eleven museum rooms of the castle in Podhorce can be found in, e.g.: See: J.K. Ostrowski, J.T. Petrus, Podhorce: dzieje wnętrz pałacowych i galerii obrazów, pp. 13-30; R. Aftanazy, Materiały do dziejów rezydencji, ed. A.J. Baranowski, vol.7a, Warszawa 1990, pp. 436-449; W. Kryczyński, Zamek w Podhorcach, Zło-czów 1984, pp. 42-89.

3 S.J., Jeszcze coś o Podhorcach..., p. 280; W. Kryczyński, op. cit., p. 90.

$4 \quad$ Księga autografów zwiedzajacych zamek $w$ Podhorcach 1923-1930 [tn - The autograph book of visitors in Podhorce castle in the years 1923 - 1930] State Archive in Karków (hereinafter ANKr), Archive of Sanguszcy (hereinafter Arch. Sang.), signature Podh.II 191. Pages and cards of the discussed book are not numbered. In the State Archive in Kraków (Wawel division) the following visitors' books of the Podhorce Castle were preserved: Księga zwiedzających zamek podhorecki 1826-1834, ANKr, Arch.Sang., signature Podh.II 76; Księga autografów zwiedzających zamek $w$ Podhorcach 1835-1898, ANKr, Arch.Sang., signature Podh.II 189, pp.1-338 in, p.; Księga autografów zwiedzających zamek w Podhorcach 1923-1930, ANKr, Arch.Sang., signature Podh.II 191, b.p., Księga autografów zwiedzających zamek w Podhorcach 1887-1935, ANKr, Arch.Sang., signature Podh.II 204.

5 Konstancja Sanguszkowa, née Zamoyska (1864-1946) - daughter of Stanisław Kostka Zamoyski and Róża Maria Zamoyska, né Potocka.In 1895 she married Eustachy Stanisław Sanguszko. She was an active member of religious and charity organizations. After the death of Eustachy Stanisław Sanguszko in 1903 she devoted herself to rising her only son, Roman Władysław Sanguszko; J.M. Marszalska, Sanguszkowa Konstancja z d.Zamoyska (1864-1946), Stownik Pracowników Książi Polskiej (herienafter SPKP), ed. H. Tadeusiewicz, Suplement II, Warszawa 2000, pp.137-138; A.Z. Sołtys, Archiwalia sanguszkowskie w zbiorach Archiwum Diecezjalnego w Tarnowie, in:Wokót Sanguszków: dzieje-sztuka-kultura.Materiały I Ogólnopolskiej Konferencji Naukowej 29-30 czerwca 2006, Ratusz, Muzeum Okręgowe w Tarnowie, Tarnów 2007, pp. 9-12.

6 Roman Władysław Sanguszko (1901-1984) - landowner, breeder of Arab horse. Son of Eustachy Stanisław Sanguszko, the governor of Galicia, and Konstancja Sanguszko née Zamoyska. In 1937 he married Wanda Krynicka 
and valuable objects from the residence. Due to this fact guests visiting the castle could not familiarize themselves with and witness all the mementos of Konicepolscy, Rzewuscy, Sobiescy or Sanguszko families previously displayed in the castle. However, they could admire magnificent architecture of the castle and splendid vistas visible from the terraces of the castle ${ }^{7}$. Adolf Szyszko-Bohusz characterized condition of the castle after the mentioned conflicts in the following words on the pages of „Sztuki piękne [tn - Fine Arts]” magazine: We remember the castle in its full glory. Alas, not much of it remained. Austrian, Hungarian and later Polish and Ukrainian soldiers quartering in the castle did not contribute to preservation of the castle collection in fine condition. The Bolshevik invasion of 1920 dispersed the collection and so the empty chambers, torn tapestries, damp ceilings and shattered pieces of furniture scattered around welcome the visitors searching for the traces of old splendor with terrified eyes ${ }^{8}$. Aleksander Czołowski and Bogdan Janusz write in a similar tone in their monograph Przeszłość i zabytki województwa tarnopolskiego [tn-Past and monuments of Tarnopolski province]: The time of war was a tumultuous and dangerous period for the castle, [...] Numerous objects were damaged. The paneling, floors, ceilings and walls were damaged but in the end the castle survived. Irreparable damages were caused by the few-months long occupation of Ukrainians and later by the invasion of Bolsheviks. As evidenced at each and every step having taken over the castle they downright devastated the remaining mementos chopping, breaking, puncturing and destroying them ${ }^{9}$. It is difficult to explicitly ascertain what memorabilia of the past visitors of the Podhorce castle could see in years 1923-1930. More significant efforts to restore castle in Podhorce to its former glory were made by its contemporary owners (Roman Władysław Sanguszko and his mother, Duchess Konstancja Sanguszko née Zamojska in the thirties of the 20th century in preparation for the coming celebrations of the 250th anniversary of the Vienna Relief which were to take place in $1933^{10}$.

The book of guests in Podhorce castle contains approximately one thousand seven hundred entries dating from 1923 to 1930 . Therefore, autographs were entered into the book across the span of seven years. This book constitutes a ,separate" document. Signatures of the visitors of Podhorce from years 1923-1930 should be placed in Księga autografów zwiedzajacych zamek $w$ Podhorcach $w$ latach 1887-1935 [tn - The autograph book of visitors in Podhorce castle in the years $1887-1935]^{11}$. The guest book from the years $1887-1935$ contains approximately one thousand records of the visitors of museum in Podhorce accumulated across the span of forty eight years. The guest book of Podhorce castle from years 1887-1935 collects autographs of individuals holding various stations and positions and coming from many different strata of society. It also contains detailed records of distinguished guests visiting the castle as well as inscriptions referring to patriotic customs and traditions or the history of the castle. The book

née Turzańska (1894-1937). He had a son, Piotr (1937-1989) with her. Later he married Germaine Lucie Armand Gontaur de Biron; A. Biernacki, Sanguszko Roman Władysław Stanisław Andrzej (1901-1984), Polski Stownik Biograficzny (hereinafter PSB), vol. 34, ed. H. Markiewicz, Wrocław-Kraków-Warszawa 1992-1993, pp. 509-510.

7 The history of Podhorce Castle was presented in, e.g.: See: R. Aftanazy, op. cit., pp.424-465; Bańburski K., Szpunar A., Zamek w Podhorcach w posiadaniu Rzewuskich i Sanguszków, „Zamoysko-Wołyńskie Zeszyty Muzealne, vol. 2/2004, pp.139-153; Z. Bania, Pałac w Podhorcach, „Rocznik Historii Sztuki”, vol.13/1981, pp. 97-170.

8 A. Szyszko-Bohusz, Podhorce, ,Sztuki Piękne: miesięcznik poświęcony architekturze, rzeźbie, malarstwu, grafice i zdobnictwu, Organ Polskiego Instytutu Sztuk Pięknych”, R. 1/1924-1925, p. 154.

9 A. Czołowski, B. Janusz, Przeszłość i zabytki województwa Tarnopolskiego, Tarnopol 1926, pp. 96-97.

10 K. Bańburski, A. Szpunar, op. cit., p.152; J.K. Ostrowski, J.T. Petrus, op. cit., pp.40-41.

11 Księga autografów zwiedzających zamek w Podhorcach 1887-1935, ANKr, Arch.Sang., signature Podh.II 204. 
discussed herein-above also includes signatures of organized groups visiting Podhorce and entries made by the contemporary owners of the castle: Konstancja Sanguszko née Zamojska and her son Roman Władysław Sanguszko ${ }^{12}$.

Among the autographs and entries in the Autograph book of visitors in Podhorce castle in the years 1923-1930 we may distinguish several different groups of signatures. The dominant group of autographs is signatures of school pupils and scouts as well as autographs of adults visiting the castle as a part of trips and excursions organized by scientific institutions. The next group is autographs of the representatives of Polish nobility and landowners. The analyzed book also contains autographs of distinguished researchers, exceptional professors and highrank clergymen. The autographs of the residents of neighboring lands can be distinguished as a separate group. Residents of towns and villages neighboring Podhorce constitute a significant part of the visitors ${ }^{13}$.

The 1923-1930 book of autographs opens with an entry by Fr. Lucjan Tokarski, Ph.D., who wrote: The participants of the school trip of pupils from the M. Kopernik III Junior High School in Tarnopol, visiting the memorial of Polish past and culture in Kresy, affix their signatures on the 6 th of May $1923^{14}$.The entry was signed by teachers and pupils visiting the castle at that time ${ }^{15}$. Autographs with a dedication alluding to the patriotic tradition and customs were also inscribed in the book by the members of the 2nd Girl Scout Team of Lwów ${ }^{16}$, 6th Girl Scout Team of Lwów ${ }^{17}$ and 1st Girl Scout Team of Złoczów ${ }^{18}$. On the 21st of May 1923 they left the following inscription in the book [...] Let the God protect the remains of the builders who erected this castle to protect the borders of our Homeland and sacrificed their lives, let us be worthy successors of our fathers ${ }^{19}$. An entry referring to the contemporary condition of the castle was made on the 31st of May 1923 by participants of a trip from Lwów. After their visit the following inscription in the guest book could be found: On the 31st of May 1923 participants of a trip from Lwów visited this castle and having witnessed its ruin with own eyes sincerely appeal to the society to resolve the burning issue of the restoration of this castle as the sole monument of our work, achievements and culture

\footnotetext{
12 See: K. Paduch, Księga autografów zwiedzających zamek w Podhorcach w latach 1887-1935 z lat 1887-1935, III Lubelska Jesień Historyczna. Materialy konferencyjne, edd. M. Dolecka, K. Jakimowicz, A. Sykała, Lublin 2015, pp. 91-105.

13 Księga autografów zwiedzających zamek...

14 Ibidem.

15 Ibidem.

16 Walerian Łukasiński 2nd Girl Scouts Team of Lwów was formed in 1912 by Maria Germanówna. Due to the vacant position of the team leader it was dissolved in the Fall of 1924. On the 15th of September 1925 girl scouts resumed activities.; I. Kozimal, Lwowska Choragiew Harcerek ZHP w latach 1911-1939, Przemyśl 2003, pp.76-79.

17 Zawisza Czarny 6th Girl Scout Team of Lwów was formed by Jadwiga Ogibowska (1906-1928). It was formed in 1922 or 1923 in Queen Jadwiga Junior High School in Lwów. It consisted of approximately 30 girl scouts: See J. z Mackiewiczów Orkiszowa, Zarys historii VI drużyny żeńskiej im.Zawiszy Czarnego, XIII Państwowe Liceum i gimnazjum im.Królowej Jadwigi we Lwowie ( $n r$ 573) lata 1879-1938/39 zachowane w pamięci; rys historyczny i działalność szkoły do roku 1939 (wybrane tematy), compiled by E. Fedyk, Kraków 2007, pp. 88-89; I. Kozimal, op. cit., pp. 85-87.

18 Queen Jadwiga 1st Scout Team of Złoczów was formed in 1914.In years 1914-1920 operations of the team were suspended due to war and Bolshevik invasion. After the war was over the team resumed activities. In years 1924-1925 girl scouts tended to the graves of fallen Polish soldiers, participated in national day celebrations and performed other duties; I. Kozimal, op. cit., pp. 238-239.

19 Księga autografów zwiedzających zamek...
} 
remaining in the frontier of the Republic of Poland; we appeal to members of parliament, authorities and common charity. We await and do not lose hope ${ }^{20}$.

Castle in Podhorce also hosted trips from towns located near the residence. On the 15th of June 1927 castle was visited by a trip from Adam Mickiewicz girls' school in Złoczów ${ }^{21}$. The other group of pupils from Złoczów visited the castle on the 29th of June $1927^{22}$. Also in 1927 the aristocratic residence was visited by scouts from Milanówek near Warsaw. Scouts from the 1st Scout Team of Milanówek ${ }^{23}$ visited the residence of Sanguszcy on the 29th of July 1927 during a trip around the frontier they were participating in between the 26th and the 31 st of July $1927^{24}$.

Apart from the already discussed organized groups Podhorce castle was visited in 1927 by, for instance, tourists from Lwów (11th of August) and organized groups from Lida (13th of August), Oleski (14th of August), Złoczów (15th of August), Kontór (21st of August), again from Złoczów (21st of August), Dub (21st of August) and Brody (22nd of August) ${ }^{25}$.

In 1928 the castle also hosted a significant number of organized groups. On the 2nd of June 1928 two separate trips visited the castle. They were: the trip from State Teaching Seminary for Men in Ursynów ${ }^{26}$ and pupils from Junior High School in Gródek ${ }^{27}$. In 1928 museum in Podhorce was also visited by e.g. pupils from Zabałcie and Wadkowice (15th of June), the youth from Niwa and Wierzbna (15th of June), pupils from Ostróg near Horyń (19th of July) and organized groups from Ronty (29th of July), Kobryń (1st of August) and Brody (19th of August) ${ }^{28}$. Apart from the school trips listed above the castle was also visited on 24th of June 1928 by students from the Academic Historian Association from the Jan Kazimierz University in Lwów ${ }^{29}$. The next group of visitors was the trip organized by Household Course Group from Olesk which visited castle on the 8th of July $1928^{30}$. Similarly to the previous year castle was also visited by scouts. On the 22nd of July 1928 the museum was visited by

\footnotetext{
20 During the First World War and the War of 1920 Podhorce Castle found itself in the area of military activity. Residence of Sanguszcy was occupied by Russian, Austrian-Hungarian, German and Ukrainian forces. Marcin Grabikowski, contemporary administrator of the castle, described the military operations of 1914-120 in great detail. See: M. Grabikowski, Zamek w Podhorcach w okresie wielkiej wojny 1914-1920: kronika Burgrabiego Marcina Grabikowskiego, Gumniska 1931, K. Bańburski, A. Szpunar, op. cit., pp.151-152; Księga autografów zwiedzajacych zamek...

21 Ibidem.

22 Ibidem.

23 In 1920 the first Boy Scout team was formed in the local Junior High School. This team consisted of both boys and girls. Boys formed the Bartosz Głowacki 18th Mazovian Scout Team whereas girls formed Orlęta Lwowskie 1st Scout Team in 1929.In 1927 scouts from Milanówek were participating in 24-day long trekking camp in the regions of Karpaty Wschodnie (Eastern Carpathians) and Podole; Z. Żuławska, Milanówek 1899-1939: dokumenty $i$ wspomnienia, Milanówek 1994, pp. 49-50.

${ }^{24}$ Księga autografów zwiedzających zamek...

25 Ibidem.

26 State Teachers' University for Men in Ursynów - school was reinstated in 1922 by Wincenty Tyrankiewicz (1887-1964).Initially he worked at the university as a teacher and later, in years 1925-1937, he took over as the principal.His wife, Olga Teresa Tyrankiewicz née Szefer (1885-1969), also worked in this school in years 19261932; E.J. Maliński, Helena i Wincent Tyrankiewiczowie: szkic biograficzny, Jelenia Góra 1989, pp. 6- 24.

${ }^{27}$ Księga autografów zwiedzających zamek...

28 Ibidem.

29 Ibidem.

30 Ibidem.
} 
the participants of 23rd Warsaw Scout Team trekking camp ${ }^{31}$. In turn, on the 19th of August 1928 the castle was visited by the group of army officers from Lwów, temporarily stationed in Biały Kamień, and their families ${ }^{32}$. Museum in Podhorce was in 1929, similarly to previous years, mostly visited by organized groups on school trips. That year the castle was visited by, for instance, a school trip from Adam Mickiewicz Junior High School in Lwów (25th of May), female students from Zofia Strzałkowska Scientific Institute in Lwów (2nd of June), Junior High School for Girls in Brody (8th of June) and Maria Konopnicka Junior High School for Girls in Tarnopol (26th of June) ${ }^{33}$. In 1929 the museum was also visited by scout teams. On the 2nd of June 1929 the castle was visited by 1st and 2nd Scout Team of Złoczów. On the 17th of July 1929 the exhibits and showpieces collected in the museum were admired by the members of Private Teaching Seminary in Brody. In turn, on the 24th of June 1929 castle was visited by students from the College of Commerce in Złoczów ${ }^{34}$.

In 1930 the museum was visited by, for instance, VIII grade pupils from King Jan III Sobieski Junior High School in Złoczów (16th February) and participants of teacher's training course in Brody (7th of July 1930) ${ }^{35}$. It is worth mentioning that on the 27th of June 1930 the residence was visited by members of gymnastic association „Sokół” [tn - The Falcon] from Brody ${ }^{36}$.

Particularly interesting dedications were left by scouts who visited castle in 1930.The first of the mentioned dedications was inscribed by scouts from Śląsk Opolski. In the book of guests they left the following inscription: For the eternal remembrance Polish Scouts from Niemce in Ślask Opolski who travel around the Poland on bikes, leave their signatures. Podhorce, 5th of July 1930. Beside the inscription there is an imprint of a stamp reading as follows: Z.H.P in Niemce, Ślask Opolski [tn - The Polish Scouting and Guiding Association, Niemce, Śląsk Opolski].Wyprawa harcerzy rowerami dookoła Polski [tn - The Polish Scouting and Guiding Association, Niemce, Śląsk Opolski, Bike Scouting Hike around the Poland $]^{37}$.The other inscription was left in the book of guests by scouts from the Greater Poland region: Jan Sobieski Scouting Team from Kościan in the Greater Poland region has

\footnotetext{
31 Bolesław Chrobry 23rd Warsaw Scout Team - formed in 1920 by A. Stażyński in Stefan Batory Junior High School. Initially it was assigned number 36 but later adopted number 23; 23 Dr. Harc. im. Kr. Bol. Chrobrego 19201930, Warszawa 1930, pp.1-3; Księga autografów zwiedzajacych zamek....

32 Ibidem.

33 Ibidem.

34 Ibidem.

35 Ibidem.

36 Gymnastic Association „Sokół” in Brody was formed in 1891. According to 1911 information it was one of 45 branches of this association operating in the Lwów region; J. Glińska, B. Serwiński, S. Zaborniaka, Budownictwo Sportowe w działalności Towarzystwa Gimnastycznego Sokół Okręgu V Lwowskiego (1884-1914), Szkice z działalności Towarzystwa Gimnastycznego „Sokól” (1867-2006), ed. S. Zaborniaka, P. Króla, Rzeszów 2010, pp. 71-74; Księga autografów zwiedzajacych zamek...

37 It is difficult to explicitly ascertain which of the Polish scout teams functioning within the structures of Polish Scouting and Guiding Association in Niemce operating in the Śląsk Opolski area visited the castle. Two scout troops, Bytomski and Raciborsko-Gliwicki, operated in the region of Śląsk in 1934.in turn, in 1924 a team operated in Opole; See: H. Kapiszewski, Związek Harcerstwa Polskiego w Niemczech: zarys historyczny ze szczególnym uwzględnieniem lat1933-1939, Warszawa 1969, pp.122-129; Księga autografów zwiedzajacych zamek...
} 
decided to visit the home and place of residence of their patron. On the 15th of July 1930 they put down their signatures in memory of the visit $t^{38}$.

School trips were primarily organized for the purpose of recreation and sightseeing. Presenting the most important monuments and historical locales in the nearest vicinity was also one of the objectives of school excursions. As an example it is worth to mention that the pupils from King Jan III Sobieski Junior High School in Złoczów went for one-day trips to, for instance, Olesk, Biały Kamień and Firlejówka. However, the greatest number of the school trips from this institution, similarly to the pupils from Adam Mickiewicz Junior High School in Złoczów, came to Podhorce. In the residence of Sanguszcy they toured the castle, the church and the magnificent park complex ${ }^{39}$. One of the pupils from the Junior High School in Złoczów recollects his stay in the castle in Podhorce during the celebration of the 250th anniversary of the Vienna Relief and describes it in the following words: The castle is a splendid and lordly residence erected on the northern slope of the rise. The spacious building, all in white, with soaring towers and resting on robust stone foundation looms over the countryside. Wide terraces surrounding the castle provide excellent view of the neighborhood.[...] Road to the castle leads through a splendidly kept park full of towering trees and alleys of carefully cut lawns, shrubs and hedges. In the northern-west of the terrace a walnut tree grows, allegedly planted by King Jan III himself.[...] On the first floor of the castle - a museum. Numerous historical memorabilia are collected here. These are: sabres, swords, Turkish yatagans, lances, bardiches, casques, chainmails, hussar armors adorned with wings, portraits, banners and tents. They [tents] stood set up in the centre of the hall and were mostly captured from Turks. It was an object lesson of history ${ }^{40}$.

The discussed book of guests also includes autographs of the representatives of Polish nobility who visited the residence, often coming in groups. On the first pages of the book, under the date of the 5th of July 1925 there are autographs of Natalia Siemieńska née Tyszkiewicz (born in 1894) ${ }^{41}$ and her husband Jan Siemieński (1894-1963) ${ }^{42}$ who visited the castle in the company of Artur Tarnowski ${ }^{43}$. Dozen or so days later, on the 19th of July 1925, the castle was visited by Adam Zamoyski from Wysock (1872 -1933) ${ }^{44}$, Jerzy Potocki from

38 The first Scout Team in Kościana was formed in 1912 on the initiative of: Teofil Jurga, Henryk Zagierski and Józef Kamiński. In 1913 the team adopted name Jan III Sobieski 1st Scout Team of Kościana. In 1930 scouts participated in 11 camps: two trekking camps, six stationary camps and three cub scouts camps. In 1930 scouts went on a 3-week trekking cap ,Following the trail of Sobieski” through the Podole region: R. Potok, K. Jankowska, 100 lat Kościańskiego Harcerstwa.Zarys dziejów 1912-2012, Kościana 2013, p. 9, p. 17, p. 90, p. 92; Księga autografów zwiedzających zamek...

39 M. Szymska, A. Drobenki, W. Gniewka-Węgrzyna, Księga pamiątkowa Gimnazjum Złoczowskiego 1873-1939, Kraków 1992, p. 19, p. 64; J. Błoński, Pamiętnik 1891-1939, Kraków 1981, p. 27.

40 W. Gniewek-Węgrzyn, Złoczów - Miasto mojej młodości, Księga pamiątkowa Gimnazjum Złoczowskiego 1873-1939, M. Szymska, A. Drobenki, W. Gniewka -Węgrzyna, Kraków 1992, pp. 267-268.

${ }^{41}$ Natalia Siemieńska née Tyszkiewicz (born 1894) - daughter of Jan and Natalia Tarnowscy. E. Borowski, Genealogie niektórych Polskich Rodzin utytułowanych, p.1, Buenos Aires-Paryż 1964, p. 80.

42 Jan Stanisław Siemieński (1894-1963) - son of Stanisław (1864-1918) and Zofia (1869-1954) Siemieńscy; Ibidem, p. 80.

43 Artur Tarnowski (1903-1984) - land owner, holder of the domain of Dzików. Member of Parliament in years 1935-1937.On the 17th of July 1931 he Married Róża Zamojska (born 1911); A. Brzozowicz, Magnateria na koneckich włościach: genealogia rodów Odrowążów, Małachowskich i Tarnowskich, Warszawa 2008, p.168; Księga autografów zwiedzających zamek...

${ }_{44}$ Count Adam Zdzisław Zamoyski (1872-1933) - son of count Stefan Zamoyski and Zofia Potocka, countess of Pilawa: E. Borowski, Genealogie niektórych Polskich Rodzin utytułowanych, p. 2, Buenos Aires-Paryż 1966, p. 63. 
Pomorze family line (1889-1961) ${ }^{45}$ and his cousin, Józef Potocki (1895-1968) ${ }^{46}$. According to the records in the book further visits of Potockis from the Pomorze region took place on the 3rd of October 1926 and the 5th of October 192947. On the 26th of March the castle was visited by members of Czartoryscy family, including, Witold Czartoryski (1864-1945) with his wife Jadwiga Czartoryska née Dzieduszycka (1867-1941).They visited the castle in company of their children: Witold junior (1908-1954), Adam Józef (1906-1998) and Piotr (1909-1993) ${ }^{48}$.

Sanguszcy princes probably received their next guests on the 16th of October 1927.At that time Ksawery Krasicki (1874-1950) with his wife Zofia Krasicka née Grocholska (born in 1889) ${ }^{49}$ and his brother-in-law Ksawery Grocholski (1903-1947) ${ }^{50}$ came to Podhorce. Signing the book they stressed that they have come to the residence in Fiat $507^{51}$. Just beside the above mentioned autographs Henryk Grocholski put down his signature and a note: First time in magnificent Podhorce, thank you very much ${ }^{52}$. Henryk Grocholski mentioned previously did not forfeit the occasion to write that he came to Podhorce castle driving Fiat $501^{53}$. Roman Władysław Sanguszko and Konstancja Sanguszko née Zamoyska put their signatures beside this inscription which indicates that they were present in the residence during the visit of Grocholscy family ${ }^{54}$. It should be noted that the indication of the cars drove by the visitors may be related with Roman Władysław Sanguszko's well known love for cars. Prince possessed a magnificent collection of cars and was a member of the board of Krakowski Klub Automobilowy [tn - Cracow Automobile Club] ${ }^{55}$.

Among the many autographs collected in the book it is worth to note that on the 20th of October 1929 the residence in Podhorce was visited by Felicja Skarbkowa née Szczepańska $(1872-1963)^{56}$. She probably came to the castle in the company of Jan Serwatowski

\footnotetext{
45 Jerzy Potocki (1889-1961) - a landowner and a senator. Grandson of the Galicia governor Alfred Potocki (1822-1889) and Maria Klementyna Potocka née Sanguszko (1830-1903) and grandson of Roman Potocki (1851-1915) and his wife Elżbieta Potocka née Radziwiłł (1861-1950). He inherited Pomorzany domain after the death of his father. He contributed to the restoration of the Pomorzany palace; A. Szklarska-Lohmannowa, Potocki Jerzy (18891961), PSB, vol.28, ed. E. Rostworowski, Wrocław-Warszawa-Kraków-Gdańsk 1984-1985, pp. 47-49; T. BagińskaŻurawska, M. Paterak, Rodowe Mauzoleum Potockich w Eańcucie, „Spotkanie z zabytkami”, no. 11/2008, pp. 23-25 .

46 Józef Alfred Potocki (1895-1968) - a diplomat. Son of Józef Mikołaj Potocki and Helena Potocka née Radziwiłł.In 1930 he married Krystyna Radziwiłł; A. Szklarska-Lohmannowa, Potocki Józef Alfred (1895-1961), PSB, vol.28, ed. E. Rostworowski, Wrocław-Warszawa-Kraków-Gdańsk 1984-1985, pp. 81-82.

47 Księga autografów zwiedzajacych zamek...

48 Ibidem; E. Borowski, Genealogie niektórych Polskich Rodzin ..., p. 2, pp. 18-20.

49 Zofia Krasicka née Grocholska (born 1889) - daughter of Tadeusz Przemysław Michał Grocholski (1839-1913) and Zofia Grocholska née Zamojska (1865-1957). Her mother was the daughter of Stanisław Zamojski and Róża Zamojska née Potocka.Zofia Krasicka née Grocholska stayed in the palace of her aunt - Konstancja Sanguszko née Zamojska; E. Borowski, Genealogie niektórych Polskich Rodzin..., p.1, pp. 55-56.

50 Ibidem.

51 Księga autografów zwiedzających zamek...

52 Ibidem.

53 Ibidem.

54 Ibidem.

55 A. Biernacki, op. cit., pp. 509-510.

56 Felicja Maria Skarbkowa née Szczepańska (1872-1963)- a social activist. Daughter of Aleksander Szczepański (1834-1918) and Melania Maria Szczepańska née Serwatowska (1842-1924). In 1892 she married Andrzej Maksymilian Fredro and in 1901 she married Aleksander Skarbek; E. Orman, Skarbkowa ze Szczepańskich Felicja Maria (1872-1963), PSB, vol.38, ed. H. Markiewicz, Warszawa-Kraków 1997-1998, pp. 33-35.
} 
(1912-1990), Wanda Serwatowska (born on 1916) and Maria Serwatowska (1908-1967) ${ }^{57}$. For the second time Felicja Skarbkowa née Szczepańska visited Podhorce in 1930. After her visit she left the following inscription in the book: Felicja Skarbkówna and her English companion Seadys Clecps, visiting on the 28th of April, wish they could have purchased some postcards or an album in memory of the visit $t^{58}$. This record provides us with several valuable pieces of information concerning visiting the museum in Podhorce. Mainly, after visiting the museum tourists did not have an opportunity to purchase a commemorative postcard or an information booklet. This should not be surprising as the Podhorce residence was a family museum made accessible to visitors due to the magnanimity of Sanguszcy family as well as their familial and social connections.

Among the signatures of numerous aristocratic families who visited the castle there are also autographs of, for instance, the representatives of Czartoryscy, Lubomirscy and Sapiehowie families ${ }^{59}$.

Across the ages the castle in Podhorce was visited by numerous distinguished scholars, researchers and high ranking clergymen. The collected autographs include, among other members of this group, an inscription by prof. Zygmunt Kamieński (1888-1969) ${ }^{60}$. Along with his students professor visited the residence as a part of a research excursion of the students of the Architecture Faculty of the University of Technology of Warsaw. As indicated in the books the group visited the castle and toured the museum pieces in Podhorce on the 8th of May $1923^{61}$. Another distinguished individual who visited the castle was the director of French Mission in Poland, General Charles Joseph Dupont (1863-1935).He stayed in Podhorce on the 21st of June 1923 in company of Remigiusz Grocholski (1888-1965) ${ }^{62}$ who wrote the following in the book of guests: I visited Podhorce accompanying General Dupont, director of French Mission in Polish Republic, in his tour of the eastern Galicia. I was pleased with the possibility to be able to show general the Podhorce castle, the jewel of Polish lands astounding even those who witnessed all Europe has to offer! ${ }^{63}$

\footnotetext{
57 These probably are the children of landowner Józef Serwatowski (1873-1940 or 1941) and Wanda Puzynanka née Kozielska (born 1881); A. Szklarska- Lohmannowa, Serwatowski Władysław Józef (1873-1940 lub 1941), PSB, vol.36, ed. H. Markiewicz, pp. 339-340.

58 Księga autografów zwiedzających zamek...

59 Ibidem.

60 Zygmunt Kamiński (1888-1969) - a painter and a graphic designer. In years 1904-1905 he studied at the Academy of Fine Arts in Warsaw and since 1908 at the Academy of Fine Arts in Kraków where he studied under the tutelage of prof. Józef Mehoffer. After graduating he moved to Paris to continue and supplement his education. In 1914 he was co-founder of the Architecture Department at Warsaw University of Technology. In years 1915-1960 he led the Free-Hand Drawing Faculty; Z. Porada, Zygmunt Kamiński (1888-1969), Olimpijczycy z Krakowskiej Akademii Sztuk Pięknych, Kraków 2014, pp. 66-68.

${ }^{61}$ Księga autografów zwiedzających zamek...

62 Remigiusz Adam Grocholski (1888-1965) - an officer of cavalry in Polish Army. Son of landowner Tadeusz Grocholski and Zofia Grocholska née Zamojska. Between the July and October of 1919 a participant of the first ever course in General Headquarters Military School. In the November of 1921 he became a military border inspector in Wołyńskie province. In 1923 he worked in Military Academic Publishing Institute and later was employed as a translator in Polish War College; A.K. Kunert, Grocholski Remigiusz Adam (1888-1965), Stownik Biograficzny konspiracji Warszawskiej 1939-1944, Warszawa 1987, pp.75-76.

${ }_{63}$ Księga autografów zwiedzających zamek...
} 
One of the distinguished guests who visited the castle was the contemporary secretary of the Marshal of the Sejm, Józef Gotard Dwernicki (1897-1944) ${ }^{64}$. He signed the book of autographs on the 25th of August $1925^{65}$. In the same year the residence also welcomed an excellent researcher and an expert on the subject of frontier castles and palaces, historian and lawyer dr Aleksander Czołowski (1885-1944) ${ }^{66}$. He stayed in Podhorce on the 29th of September 1925 in the company of senator dr Henryk Orliński (1873-1953) ${ }^{67}$, president of the County National Organization, and heritage conservationist Bogdan Janusz (1888-1930) ${ }^{68}$. The researchers visited the castle in order to procure and gather materials for the publication they were working on: ,Zabytki Województwa Tarnpolskiego [tn - Historical monuments and relics of the Tarnpolski province]. This monograph was published in the following year (1926) and was one of the first regional monographs in Poland ${ }^{69}$. The Publishing Committee responsible for the publication of the mentioned monograph and providing help and support to dr Aleksander Czołowski and Bogdan Janusz was headed by voivode of Tarnopol - dr Lucjan Zawistowski (born in 1876) ${ }^{70}$. This is probably why he visited the residence in Podhorce twice: on the 6th of August 1925 and on the 11th of October $1925^{71}$. According to the records in the book dr Aleksander Czołowski visited Podhorce again on the 30th of August 1929.

64 Józef Gothard Dwernicki (1897-1944) - a lawyer. Graduated from law schools in Lwów and in Warsaw. In 1920 he served in Prince Józef Poniatowski 8th Ulan regiment. In years 1924-1930 he worked in the office of Marshal of the Sejm. He worked during the period of Maciej Rataj's and Ignacy Daszyński's tenure as Marshals of the Sejm. In 1928 he married Jadwiga Serwatowska (born 1905); D. Chłapowski, Dwernicki Józef Gothard (1897-1944), Ziemianie Polscy w XX wieku: słownik biograficzny, ed. T. Epsztein, S. Górzyński, B. Konarska, J. Leskiewiczowa, pt. 9, Warszawa 2010, pp. 69-70.

65 Księga autografów zwiedzających zamek...

66 Aleksander Czołowski (1865- 1944) - a lawyer, an archivist and a researcher. In 1890 he graduated from the university of Lwów as a Doctor of Philosophy. In 1890 he became a member of Easter Galicia Preservationist Circle. Since 1891 he has been working as an archivist in Lwów City Archive. He contributed to the founding of Historical Museum of Lwów, Lwów City National Gallery and King Jan III Sobieski National Museum; E. Laszka, Działalność naukowa Aleksandra Czołowskiego (1865-1944), Łódź 2004, pp.13-15.

${ }^{67}$ Henryk Orliński (1873-1953) - an educationist, a Republic of Poland senator. In 1897 he studied German philology at the Department of Philosophy at the Jagiellonian University in Krakow. He worked as a teacher in, among other places, Brody and Tarnopol. He was an active member of numerous institutions including Examination Commission for public school teachers in Tarnopol. In years 1922-1927 he was a Republic of Poland senator; B. Łopuszański, Orliński Henryk (1873-1953), PSB, vol.24, ed., E. Rostworowski, Wrocław-Warszawa-KrakówGdańsk 1979, pp.209-210.

68 Bogdan Janusz (1888-1930) - archeologist, publicist. In 1907 he worked in Museum of Szewczenko in Lwów. Before the First World War he was and editor of „Kurier Lwowski” and creator of „Exlibris” bibliophile annual. In the years 1923-1926 he was a heritage conservationist in the Lwów region; H. Burchard, Janusz Bogdan (18881930), PSB, ed. K. Lepszy, Wrocław-Warszawa-Kraków 1962-1964, pp. 587-588.

69 A. Czołowski, B. Janusz, op. cit., pp. V- VIII; H. Burchard, op. cit., pp.587-588.

70 Lucjan Zawistowski (born 1876) - a lawyer and a self-governing authorities official. In 1899 he graduated as a Doctor of Law from the Jagiellonian University in Kraków. In the years 1900-1918 he work in, e.g. Przeworsk and Tarnów starosty.In the years 1923-1927 he was a voivode of the Tarnopol region; Kto byt kim w Drugiej Rzeczypospolitej, ed. J.M. Majchrowski, Warszawa 1994, p.176.

${ }^{71}$ Księga autografów zwiedzających zamek... 
At that time he was accompanied by representatives of Jan Kazimierz University in Lwów: dr Eugeniusz Doliński (born in 1887) ${ }^{72}$ and dr Kazimierz Wais (1865-1934) ${ }^{73}$.

It is also worth noting that on the 16th of September 1926 Podhorce was visited by the archivist and librarian of Sanguszko family, Mikołaj Piotrowski (1874-1931) ${ }^{74}$. According to the book of autographs he visited the residence again in May of 1930. On the day of his departure, 26th of May 1930, he left the following inscription in the book: Touched by the beauty and moved by the past I am saddened to leave Podhorce ${ }^{75}$.

The residence in Podhorce was also toured by the contemporary suffragan of Lwów and later bishop of the Tarnów diocese - fr. Franciszek Lisowski (1876-1939) ${ }^{76}$. On the 14th of May 1929 he left the following dedication in the book of guests: With cordial and sincere gratitude for Old Polish hospitality and with blessings - Fr. Franciszek Lisowski, suffragan bishop of Lwów ${ }^{77}$.

The historical relics collected across the span of ages in Podhorce were on the 13th of July 1929 toured by Polish Army major and medicine practitioner, dr Kazimierz Maj (1885$-1943)^{78}$ accompanied by his wife Teodora Kończa (departed, 1970) ${ }^{79}$. Another autograph of a scientist and researcher was inscribed in the book on the 11th of June 1930. On this day Podhorce castle was visited by Ryszard Minchajmer (1907-1959) ${ }^{80}$, engineer from Warsaw.

72 Eugeniusz Doliński (born in 1877) - a medical practitioner, Doctor of Medical Sciences. He was a Chief Medical Doctor of Lwów and a lecturer in the Medicine Department at the Jan Kazimierz University in Lwów. He was arrested on the 9th of April 1940 and in 1941 he was sentenced to 5 years in labor camp; J. Draus, Uniwersytet Jana Kazimierza we Lwowie w 1918-1946: portret kresowej uczelni, Kraków 2007, p. 94.

73 Kazimierz Wais (1865-1934) - a philosopher and theologian. He completed theology course at Theology Institute in Przemyśl and at the Gregorian University in Rome. In 1889 he was ordained into the priesthood. Since 1908 he has been affiliated with University of Lwów where he was a professor of Christian theology and fundamental theology at the Theology Department; J. Draus, op. cit., p.37; Księga autografów zwiedzających zamek...

74 Mikołaj Piotrowski (1874-1931) -an art historian and librarian. He was hired by Sanguszcy as a librarian in Gumniski. He was also curator of the book collection in Podhorce. He contributed to the publication of M. Grabikowski's book entitled Zamek podhorecki w okresie wielkiej wojny 1914-1920 [tn - Castle in Podhorce in the period of Great War 1914-1920] and other works; J.M. Marszalska, Piotrowski Mikołaj (1874-1931), SPKP, supplement no. 2, ed. H. Tadeusiewicz, Warszawa 2000, p.124.

75 Księga autografów zwiedzających zamek...

76 Franciszek Lisowski (1876-1939) - a suffragan of Lwów and bishop of Tarnów. He studied theology at the University of Lwów. Later he continued education at the Gregorian University in Rome. In years 1912-1933 he worked at the Jan Kazimierz University in Lwów. On the 27th of January he was appointed to the position of Bishop of Tarnów; B. Kumor, Lisowski Franciszek (1876-1939), PSB, vol.17, ed. E. Rostworowski, Wrocław-Warszawa-Kraków-Gdańsk 1972, pp. 472-473.

77 Księga autografów zwiedzających zamek...

78 Adam Ryszard Minchejmer (1907-1959) - an engineer and a mechanist. In years 1926-1930 he studied at Mechanics Faculty at the Warsaw University of Technology. Until the start of the World War II he worked in National Engineering Works Car Factory in production of Fiat 508. In 1935 he married Maria Małgorzata Wodzińska; J. Piłatowicz, Minchejmer Adam Ryszard (1907-1959), PSB, vol.21, ed. E. Rostworowski, Wrocław-WarszawaKraków-Gdańsk 1976, pp. 282-283; Księga autografów zwiedzajacych zamek...

79 Księga autografów zwiedzających zamek...

80 Adam Ryszard Minchejmer (1907-1959) - an engineer and a mechanist. In years 1926-1930 he studied at Mechanics Faculty at the Warsaw University of Technology. Until the start of the World War II he worked in National Engineering Works Car Factory in production of Fiat 508. In 1935 he married Maria Małgorzata Wodzińska; J. Piłatowicz, Minchejmer Adam Ryszard (1907-1959), PSB, vol.21, ed. E. Rostworowski, Wrocław-WarszawaKraków-Gdańsk 1976, pp.282-283.; Księga autografów zwiedzajacych zamek... 
During the tour of the castle he could have met an avid enthusiast of cars - the contemporary owner of the castle, Prince Roman Władysław Sanguszko ${ }^{81}$.

Furthermore, on the 15th of August 1930 the castle was visited by the long-time employee of the Ministry of Foreign Affairs, minister Zdzisław Okęcki(1874 -1940) ${ }^{82}$. The minister visited the castle in the company of his wife Zofia Okęcka (1878-1963) and the previously mentioned Felicja Skarbkowa née Szczepańska ${ }^{83}$.

The residence of Sanguszcy in Podhorce was also toured by travelers in the Interwar period. The first dedication of a traveler in the Podhorce book of autographs comes from the 11th of July 1928. Kazimierz Zawierucha-Łaczmański wrote: In my trek across Poland from Busk near Gdańsk I visited the castle of Sanguszcy princes. Falcon marching and running across Poland ${ }^{84}$. Mieczysław Sobolewski was another tourist-traveler hiking across Poland who on the 13th of November 1928 signed the book of guests. He wrote: Poland is a great nation, it is prudent to learn about it. In turn, on the 17th of September 1929 the book was signed by a traveler Tadeusz Wichczeski participating in a sightseeing trip around Poland ${ }^{85}$.

Autographs of the residents of neighboring areas constitute a significant part of the autographs inscribed in the 1923-1930 book of guests of Podhorce castle. These are the autographs and signatures of private persons coming from, for instance, Olesk, Brody, Złoczów, Stanisławów, Biały Kamień or Podhorce itself ${ }^{86}$.

The discussed book of guests of the Podhorce castle contains approximately one thousand seven hundred autographs inscribed across the span of 7 years. Undoubtedly the autographs of members of organized groups coming to Podhorce constitute the largest part of the collected signatures. In turn, the largest part of the organized groups visiting Podhorce castle in years 1923-1930 consists of the school trip participants from the neighboring areas. After Poland regained its independence the Podhorce residence and collection gathered therein were an excellent history lesson. In such a short period (after Poland regained independence) forming the national awareness and consciousness of the youth was extremely important. The book of guests also proves that local residents were interested in the history of their region and visited Podhorce in great numbers. In the analyzed document a major group of autographs consists of signatures of distinguished researchers, engineers and clergymen ${ }^{87}$. The book of guests dated on years 1923-1930 also contains autographs of the representatives of squirearchy and landowners, however, they are less numerous than in the book of guests dated on years 1887-1935 when visits and trips organized by representatives of this particular social circle

\footnotetext{
81 A. Biernacki, op. cit., pp. 509-510. Gdańsk 1978, pp. 663-664.

83 Księga autografów zwiedzajacych zamek...

84 Ibidem.

85 Ibidem.

86 Ibidem.

87 Ibidem.
}

82 Zdzisław Narcyz Józef Okęcki (1874-1940) - a diplomat. He graduated with a degree in law from the Innsbruck University. Next he started work in the Ministry of Foreign Affairs. In 1914 he became the director of Policy and Diplomacy Department. In 1921 he was appointed to the position of envoy extraordinary and minister plenipotentiary of the Second Republic of Poland in Kingdom of Serbs, Croats and Slovenes. In 1928 he was the representative of Polish government in Tokyo. On the 1st of June 1930 he was recalled. In 1905 he married Zofia Skarbek; A. Piber, Okęcki Zdzisław Narcyz Józef (1874-1940), PSB, vol. 23, ed. E. Rostworowski, Wrocław-Warszawa-Kraków- 
constituted the dominant group of the visitors of the museum ${ }^{88}$. The presented book of guests includes a rather meager number of the signatures of foreigners, however, due to being inscribed in handwriting these are exceptionally hard to decipher. Owing to the period of creation the discussed book also includes autographs of soldiers, however, due to also being inscribed in handwriting these signatures are borderline impossible to decipher. It must be stressed that the vast majority of inscriptions in the book was written down with a pencil which resulted in significant difficulties in deciphering the autographs. The dates recorded beside the signatures allow us to establish that the museum was visited by the greatest number of guests in summer and in fall. This is perfectly understandable. In summer and in fall the journey to the castle and travelling in general were easier and longer day allowed visitors to tour the residence in peace ${ }^{89}$. On the grounds of the analysis of the 1923-1930 book of guests we may declare that the great interest in the Podhorce residence and relics of the pasts gathered therein sparked in the 19th century still continued in the 20th century.

\section{The autograph book of visitors in Podhorce castle in the years 1923-1930 Summary}

Podhorce is one of the greatest aristocratic residences. The owners of the palace were members of the families: Koniecpolscy, Sobiescy, Rzewuscy and Sanguszko. Waclaw Rzewu-ski (1709-1779) created in Podhorce a huge collection of works of art, he founded an armory, an archive and a library. Whereas Leon Rzewuski (1808-1869) gave museum character to the collection gathered in the palace. After visiting the residence the guests signed in the guest book of the palace. Based on the analysis of the guestbook from the years 1923-1930 it can be concluded that the palace was visited by representatives of different social strata. The largest group were the excursions organized by scholarly institutions (school children, scouts, students). The document includes signatures of the representatives of the polish gentry, distinguished professors, scientists, researchers and senior clerics. The presented book contains about one thousand seven hundred autographs, that had been placed in the book for seven years of its conduct. A significant number of signatures in the document confirms the enormous interest in the Podhorce collection in the twentieth century.

Keywords: The autograph book, Podhorce, Rzewuscy, Sanguszkowie

About the author: Katarzyna Paduch - graduate of the history course at the Cardinal Stefan Wyszyński University in Warsaw.Currently she is a post-graduate doctoral course student of the Faculty of History and Social Sciences at the Cardinal Stefan Wyszyński University and prepares doctoral thesis entitled „Biblioteka rodowa Rzewuskich h. Krzywda w Podhorcach w XVIII i XIX wieku. [tn - The family library of the House of Rzewuski in 18th and 19th century in Podhorce".

88 Compare with: Ibidem; K. Paduch op. cit., pp. 91-105.

${ }^{89}$ Księga autografów zwiedzających zamek... 